\title{
The effects of the economic crisis on public research: Spanish budgetary policies and research organisations
}

\author{
Laura Cruz-Castro and Luis Sanz-Menéndez
}

CSIC, Institute of Public Goods and Policies (CSIC-IPP)

C/ Albasanz 26-28, 28037 Madrid, Spain

Luis.Sanz@csic.es

Submitted to Technological Forecasting and Social Change

The economic crisis of recent years provides an extremely valuable context for the study of the effective role which R\&D policies have had for governments, both as a potential tool for exiting from the crisis and as an object of fiscal consolidation. The discourse of governments and international organizations often connect actions to cope with the crisis with reforms and changes in many areas, such as R\&D. However, in practice overarching fiscal consolidation policies could be damaging opportunities to establish government strategies to reform and improve the efficiency of the sector.

This paper analyses the impact of the crisis on Spanish R\&D budgets and on a public research system characterized by low organisational autonomy and limited strategic capacity. We argue that the fiscal consolidation measures adopted have reduced the capacity of governments to direct the public R\&D system. Budget cuts, together with regulations emphasising administrative controls, have reduced the government's capacity to define spending priorities, limited the ability of research organizations to adapt to the new situation and increased the levels of uncertainty within the system and reduced trust among actors.

When the policy dilemma between control and reform is resolved in favour of the former, it is likely that public research organizations will lose autonomy as a collateral effect of the crisis. We argue that the Spanish public sector research system is poorly equipped to resist the crisis and adapt to an environment of shrinking resources. In this sense, the lesson to be learned may be that organisational attributes are apparently critical in the long term and that autonomy should not be undermined.

Keywords: crisis impact; public R\&D budgets; GBAORD; R\&D funding; government spending; research policies; research organisations; universities; reforms. 


\section{Introduction}

The recent financial crisis has become an economic downturn that has significantly affected private investment in Research and Development (R\&D). At the same time, in most countries it has also been transformed into a fiscal and public debt crisis leading to changes in budgets and regulations affecting R\&D policies and impacting on the public research sector. Despite some worldwide trends, there is evidence that the slowdown and recession are affecting countries and R\&D and innovation systems in very different ways.

In Southern and Eastern European countries the economic crisis has hit hardest and the negative impact of the crisis on the R\&D systems has been more serious. The crisis has prompted a change in spending priorities together with a change in citizens' preferences regarding public expenditure. In recent years, academic journals such as Science and Nature, and even European newspapers, have regularly reported the negative trends in research and science in these countries highlighting the existence of "budget cuts" ${ }^{1}$, "shutdown of research institutions" ${ }^{2}$, "financial collapse of research centres", "brain drain dynamics", "loss of trust", etc.

The lagged effect of past R\&D investment and the impact of budget cuts on R\&D funds, have allowed governments in many countries to assert that output indicators are positive. However, it is becoming evident that despite several years of convergence dynamics among latecomer countries, the crisis has revealed structural deficits that are likely to widen the R\&D gap and have negative long term consequences for those countries when recovery starts. Although the crisis appears in government discourses as an opportunity for reform in R\&D policies and public sector research ${ }^{5}$, real policy measures have tended to follow a homogeneous top-down approach determined by the Treasury and Financial Ministries, without much consideration of the specificities of the research policy area; they have focused on a core objective (the reduction of public expenditure) and a secondary one (the reduction of the political conflict and public salience of the issues at stake).

However, despite the visibility, relevance and importance of the public budget cuts in science, we lack systematic analyses of the impact of the crisis on the public R\&D system in those countries most affected, with some partial exceptions. We even lack a descriptive picture of the budget cuts among countries. Although university dynamics in the context of the crisis have attracted some attention, very little is known about the institutional and organizational constraints of public research centres in coping with the crisis and preparing for the future.

The aim of the paper is twofold. Firstly, to analyse the effects of the economic crisis on the R\&D system, placing the Spanish case in a broader international context and, secondly, to account for the budget dynamics and policy measures taken by Spanish governments and their implementation

\footnotetext{
${ }^{1}$ After some years of official denials, the issue was recognized by the new State Secretary for Research, Development and Innovation, Carmen Vela, in Nature, vol. 486, issue 7401, 6 June 2012, p.7.

${ }^{2}$ For example, layoffs in research institutes reported in Nature , 1 November 2011, doi:10.1038/news.2011.623

${ }^{3}$ See, "Spain's Research Council Approaches Bankruptcy", Science vol. 341, 19 July 2013, p. 225.

${ }^{4}$ See "Research Cuts Will Cause 'Exodus' From Spain" Science vol. 336, 13 April 2012, p. 139-140.

${ }^{5}$ See Carmen Vela's contributions, titled "Turn Spain's budget crisis into an opportunity" mentioned in footnote 1.
} 
in the public research sector. We aim to undertake a comprehensive analysis of the changes in public resources available for R\&D policy and a qualitative appraisal of the budgetary regulation and control measures implemented in public sector research organizations.

We argue that general fiscal consolidation measures, taken as a reaction to the economic crisis, have reduced the government's ability to manage the public R\&D system, due to their lack of selectivity. Budget cuts, together with regulations emphasizing administrative controls, have reduced the government's capacity to define spending priorities, increased the levels of uncertainty within the system and reduced trust among actors. We further claim that Spanish public sector research organisations (PROs), due to their low levels of financial and strategic autonomy, are poorly equipped to overcome the crisis and adapt to the new environment of shrinking resources.

The paper is organised as follows. In section 2 we review some of the previous studies that have addressed the effects of the crisis on R\&D systems. Section 3 is devoted to the construction of the empirical case, presenting a comparative macro analysis in order to locate Spain in the broader European context, and an in-depth account of the Spanish public research budgets and some policy measures taken in the context of the crisis. In section 4 we advance some concluding remarks linking the evidence presented with the institutional features of the Spanish R\&D system and public research organizations.

\section{Previous studies}

Most analyses have focused either on the macro level, monitoring the evolution of the figures on $R \& D$ expenditure, or on the understanding of firms' investment behaviour in relation to R\&D; such studies are either very general analyses with modelling linked to abstract theory or descriptive analyses with basic indicators directly related to R\&D activities.

Much of the literature in the area of understanding the effects of the ups and downs in economic growth refers to company behaviour and investment in R\&D. Much of this work has been related to the literature on business cycles. For example, Comin and Gertler (2006) and Barlevy (2007) provide insights into the pro-cyclicality of R\&D investments in recent decades. More recently the OECD (2009) has made it clear that private investments in innovation are mainly procyclical and decrease significantly during economic downturns. In the same vein, Archibugi and colleagues (Archibugi and Filippetti 2011, Filippetti and Archibugi 2011, Archibugi et al. 2013) have found evidence to support the notion that the 2008-2009 global crisis has negatively affected European companies' investment in innovation and reduced aggregate private investments in R\&D. However some other evidence (Cincera et al. 2011) suggests the existence of different types of company responses, including a group of firms that increase their R\&D investments in years of crisis with the expectation of gathering the benefits of the upswing to come. Similar types of findings are available for firms in Latin American countries (Paunov 2012) or in Eastern Europe (Correa and Lootty 2011). Additionally, some recent research has found evidence that location and regions matter in explaining the resilience of company R\&D investments during the crisis (Holl and Rama 2015; CruzCastro et al. 2015). 
International organisations (OECD, the World Bank) and the European Union have developed several normative arguments stating that, in periods of economic crisis, governments and countries should invest (and spend) more on research, development and innovation, as a way of creating solid foundations and to prepare for the next cycle of growth, and also as a way of compensating for the reduction of private investment. This countercyclical normative statement on the uses of government R\&D budgets informs much of the public political discourse on the role of R\&D in the competitive advantage of nations but, when confronted with reality, does not find much empirical support. The current management of the crisis reveals that most governments disassociate themselves from their own normative discourses. In fact, the empirical literature on the effects of the crisis on science policies, R\&D government budgets and on public research organizations is less abundant than that analysing private investment in R\&D.

A recent contribution from Kim (2014), using data on the Gross Expenditure on R\&D (GERD) funded by governments under the analytical framework of the varieties of capitalism (Hall and Soskice 2001), argues that in the long term (1981-2009) the countries that fit in the "Coordinated Market Economies" type (Scandinavia, Germany, Japan, etc.) have used R\&D funded by government in a countercyclical way, while this has not been the case in "Liberal Market Economies" (Anglo-Saxon) and "Mixed Market Economies" (France and Southern European countries). However the data used by Kim, while allowing the monitoring of the cycles in private investment and the public funding of private $R \& D$, does not allow the monitoring of the budgetary effort of countries in support of the $R \& D$ system, which is in fact the most direct measurement of government behaviour.

In this vein, some descriptive analyses have addressed the impact of the recent economic downturn on governments' science and technology (S\&T) budgets across the EU28 countries. For example, Makkonen (2013), using Government Budget Appropriations and Outlays for R\&D (GBAORD) data, shows that most EU countries follow pro-cyclical patterns in which S\&T budgets diminish in the context of negative economic growth. Public budgets for R\&D appear to increase in times of economic prosperity and decrease in years of recession or slowdown. However there is not a clear analysis of which areas of government $R \& D$ budgets are most affected, if money is directly transferred to public research organisations or instead that funding is discretionary and competitive, or if cuts affect resources for basic science or alternatively money supporting innovation, etc. On this point, it is important to note that a significant part of government spending is quite rigid and less responsive to the economic cycle (e.g. Afonso and Tovar 2012).

We should also acknowledge the lack of a proper theory of the impact of economic downturns on the activity of the public research sector; several intervening economic and political factors tend to weaken causality claims. When analysing how governments deal with budget cuts and define spending priorities in the context of economic crises it is important to bear in mind that politics shape economic and fiscal policies. There is abundant literature on the factors shaping government preferences over budgets, but most of the empirical evidence refers to welfare policies (e.g. Jacoby 1994 or Blekesaune and Quadagno 2003). The analyses regarding public R\&D budgets are fewer and less consistent, despite the fact that, in some countries or regions where the crisis has been 
very acute, the support of citizens for public spending on S\&T has increased (Sanz-Menéndez and Van Ryzin 2015).

While there is a significant amount of literature on general reforms in government, and even articles connected to the economic downturns (e.g. Tanzi and Schuknecht 1997) there is much less on the reforms of public research institutions (some exceptions are Boden et al. 2004; OECD 2011) and these are not usually connected with the economic downturns. Additionally there is neither a rigorous comparative study of government R\&D budgets in times of recession, but instead some snapshots (e.g. the reports of the European University Association on the crisis of funding for universities in Europe), nor systematic country case studies. National case studies, if properly designed, can be very insightful; for example, in an analysis of the Greek experience, Kastrinos (2013) argues that periods of crisis are not suitable for major reforms of R\&D systems, even though they may seem to provide political opportunities for reform; economic crises, he claims, can undermine trust between governments and the research community, producing significant barriers to reform. Instead, he highlights the importance of continuity and stability in the institutional environment.

The European Commission (Izsak et al. 2013) has recently reviewed the qualitative and quantitative dimensions of the impact of the crisis on research and innovation policies. The two critical dimensions highlighted relate to cuts in public R\&D budgets and to the increasing difficulties in retaining researchers or, in general, R\&D human resources and avoiding the brain drain. The study shows that countries regarded research and innovation as a way out of the crisis and protected public R\&D activities in a countercyclical way from 2008 to 2010; however, the study also recognises that maintaining funding levels has become much more difficult since 2011 . Moreover, the decline in government R\&D expenditure did not always coincide with a general decline in other government expenditure, indicating that R\&D budgets are not "protected funding lines", as often claimed. On the policy side, the country cases included in the EC report show that loan-based instruments cannot replace grants and are not a straightforward solution to finance R\&D in Greece, Spain or Portugal. The report also points out that in many countries tight R\&D budgets have led to problems regarding the retention of skilled human resources, who have been emigrating due to the instability of the system, poor career prospects and salary cuts. Moreover, this trend of negative highly skilled migration has been coupled with a decrease in higher education expenditure in several countries, including Spain, Ireland, Italy, Portugal, Romania and the UK.

As regards output, there is disperse evidence on the effects of the economic crisis on research performance, measured by the publication of academic papers or patents at the national level. It is probably too early to monitor the impact of the crisis on the different countries' $R \& D$ and innovation performance, but there exist some descriptive analyses showing that the reduction of resources dedicated to scientific activity in the context of the economic crisis negatively affects scientific production. For example, a study of the 2001 crisis in Argentina (Miguel et al. 2010) confirms the negative impact in terms of the quantity of papers produced. More recently (De Moya et al. 2014), there has been evidence of backward trends in terms of quality indicators related to 
excellence and leadership worldwide as a result of the crisis in Spain; these analyses, nevertheless, often lack a proper explanation of the mechanisms by which these effects are produced.

Institutional dimensions are almost completely ignored in existing studies of the effects of the crisis on the research system; these dimensions include not only the availability of resources, but also key factors like funding models or the degree of autonomy, managerial flexibility and the discretion of research managers to adjust locally to the changing environment and to attempt to cope with the negative effects of the crisis. It is possible to identify different ideal types of public science systems which help to frame the predominant institutional models in different countries. Depending on the relative dominance of the state agency, Whitley (2010) distinguishes between state-coordinated, state-delegated and employer-coordinated systems. In the first, the state retains considerable control over resource allocation and employment; in the second, scientists are employees of public universities and public research organizations but these organizations remain largely funded and regulated by the state; in the last, employers are much more able to determine employment conditions, resource allocations and organizational structures independently of the state, but have to obtain most of their resources competitively from a variety of sources. The Spanish public science system fits within the second category, and has some institutional features which, we will argue, locate PROs in a difficult position to cope with the crisis.

It is therefore to be expected that the impact of the crisis will vary across countries and institutions, depending, among other things, on the way in which research organizations are funded and the degree of autonomy and managerial flexibility. Having the majority of resources secured by public budget appropriations might be beneficial for newcomer systems that need to build up infrastructure and establish the basis for projects; this was the Spanish case some years ago. Nonetheless, it has become evident that such funding portfolios become problematic in the case of severe budget reductions because they increase the vulnerability of PROs in several ways. Firstly, drastic budget cuts produce instability, uncertainty, a worsening of employment conditions and a loss of confidence in institutions, prompting the emergence of some of the individual responses envisaged by Hirschman: exit, voice, loyalty and neglect (Hirschman 1970; Rusbult et al. 1982). Secondly, in a sector heavily dependent on public funding sources, financial crises are likely to lead to a net loss of human resources; this not only precludes sustained production but also influences the reputation of organisations within their field as regards career prospects. Thirdly, due to the rigidity of an important part of government spending on $R \& D$, cuts are implemented where reductions are easier, i.e. competitive funding. These self-reinforcing dynamics are likely to amplify the negative effects of the budget measures over time.

\section{The impact of the crisis on R\&D and innovation: the Spanish case}

Since our analysis is focused on the Spanish case and on R\&D budgets, we will use mainly Spanish data sources that cannot be easily or automatically compared with other international or country data. However, despite some problems of comparability, the available international data related to 
R\&D provides a framework with which to position the Spanish case in a broader international context.

\subsection{Spain in the broader context}

In order to establish a sound comparative framework, we have limited the comparison to a set of EU countries similar to Spain (Portugal, Italy and Greece); this group of countries was labeled by a UK economic journal, and incorporated into the EU argot, as the PIGS (Portugal, Italy, Greece and Spain). These are a set of southern European nations which have been suffering severely from the crisis and which share similar attributes regarding their R\&D and innovation systems: less developed, a lower performance, a smaller role of business R\&D and a minor role of innovation in their economies; all these factors increase the dependence of the R\&D system on public investment and amplify the role of the government in funding R\&D. All of them are part of the group of 'moderate innovators' (European Commission 2015).

In addition to the PIGS we have also selected two other countries (one large and another small) which are not as radically different to Spain as, for instance, the Scandinavian countries (excellent R\&D performers) or the eastern European countries (poor performers), but which are less affected by the crisis and maintain a better position than the PIGS in terms of innovation capabilities: the countries chosen are France and Belgium. These nations are much closer than the PIGS to the average values of the EU in economic and R\&D indicators and are included under the category of 'innovator followers' (EC 2015). The six countries are in the Eurozone and are included in the category of "mixed market economies" (Hall and Soskice 2001).

\section{a) The economic crisis}

It is well known that 2008 displayed a severe downturn in European growth rates, with similar levels for all countries, a recovery in 2009 and the start of a deep recession in 2010, in the context of the debt crisis of Greece and other countries, affecting the Southern European area more than other nations. Spain, Greece, Portugal and Italy have had negative annual growth rates for the last three years, while the EU-28 average and the other two countries in the comparison have fared better (European Commission 2014).

Growth rates provide an idea of general economic dynamics, but we prefer to examine the crisis in terms of the wealth of citizens and convergence within the EU. In this sense, Figure 1 presents the evolution of GDP per capita (in real terms and considering power purchasing standards -PPS) for the countries selected. As can be observed, the PIGS had been involved in a long-term process of convergence with the rest of the European countries and the average values of the EU, despite the fact that for Italy this movement was backwards. However, this process of convergence halted with the crisis and since then a significant backward movement for all these countries can be observed. 
Figure 1. Evolution of GDP per capita (in purchasing parity standards). Index numbers (Eu-28 $=100$ ). 20022013

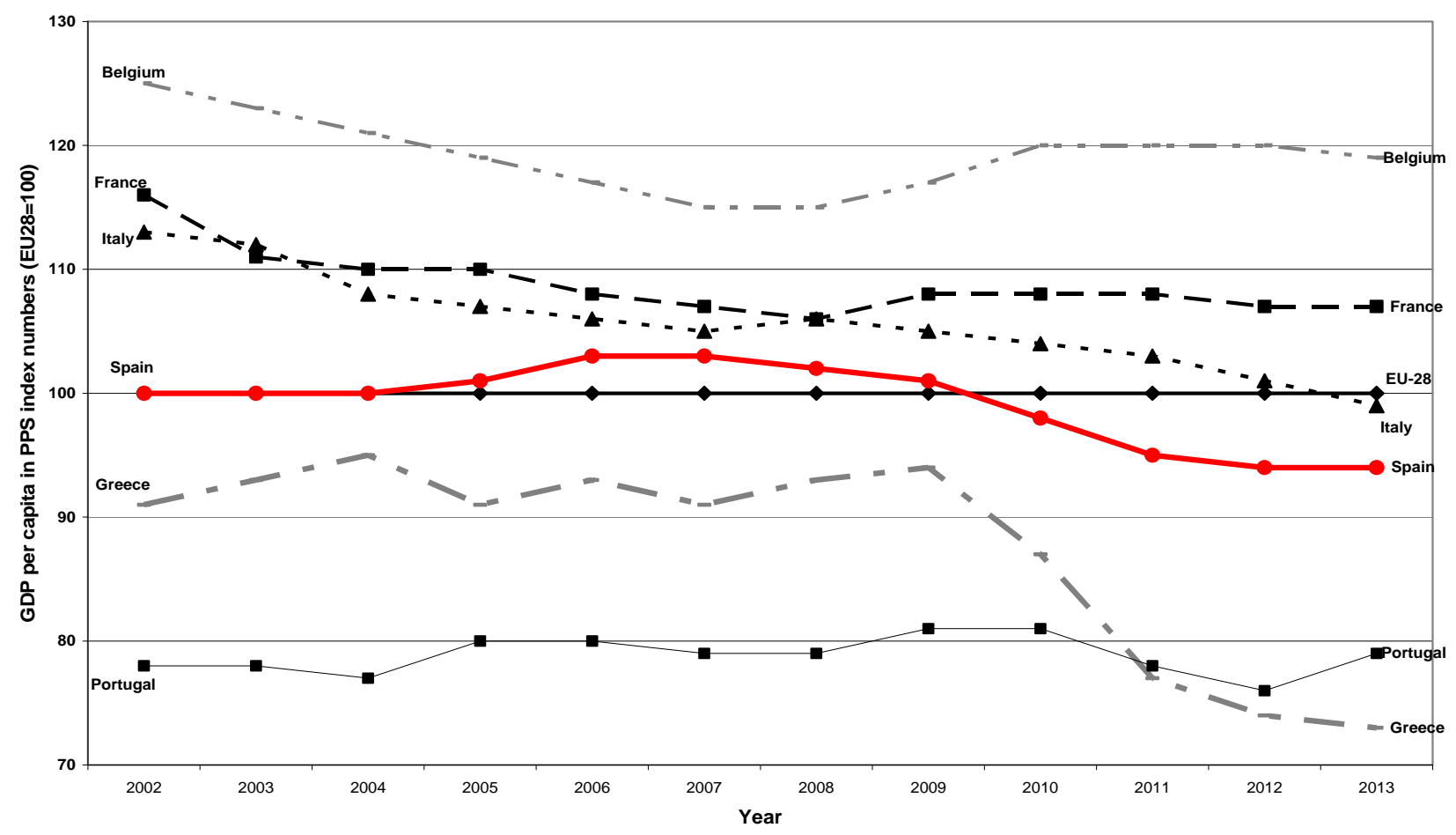

Source: Eurostat. http://ec.europa.eu/eurostat/eurostat/tgm/table.do?tab=table\&init=1\&plugin=1\&language=en \&pcode=tec00114

Spain, along with other southern European countries, has been hit by the crisis harder than other countries. The process of economic convergence has reversed. The decrease of economic activity levels, the reduction in the size of the economy and increasing unemployment have reduced government income and drastically increased the cost of unemployment insurance and, in parallel, the cost of financing the debt due to the increase in interest rates.

\section{b) The R\&D system}

Turning more specifically to the effects of the crisis on some general indicators of the R\&D system, Figure 2 presents the general evolution of the main R\&D indicator available for international comparisons: the evolution of the intensity of R\&D in the different countries (GERD as a share of GDP). The figure shows the indicator in convergence terms with respect to the average value of the EU28 for each year. We can see that while Italy and Greece were more or less stagnant in relative terms, Spain and Portugal improved in terms of convergence in the early years of the previous decade; however, it seems that this process halted in 2008-2009 and the gap began to broaden once more. Moreover, Spanish intensity in researchers per thousand workers in the labour force is moving backwards and increasing the gap with the EU28, mainly due to its high unemployment levels. 
Figure 2. Evolution of convergence in R\&D intensity [GERD over GDP in index numbers (EU-28 =100)]. 2000-2012

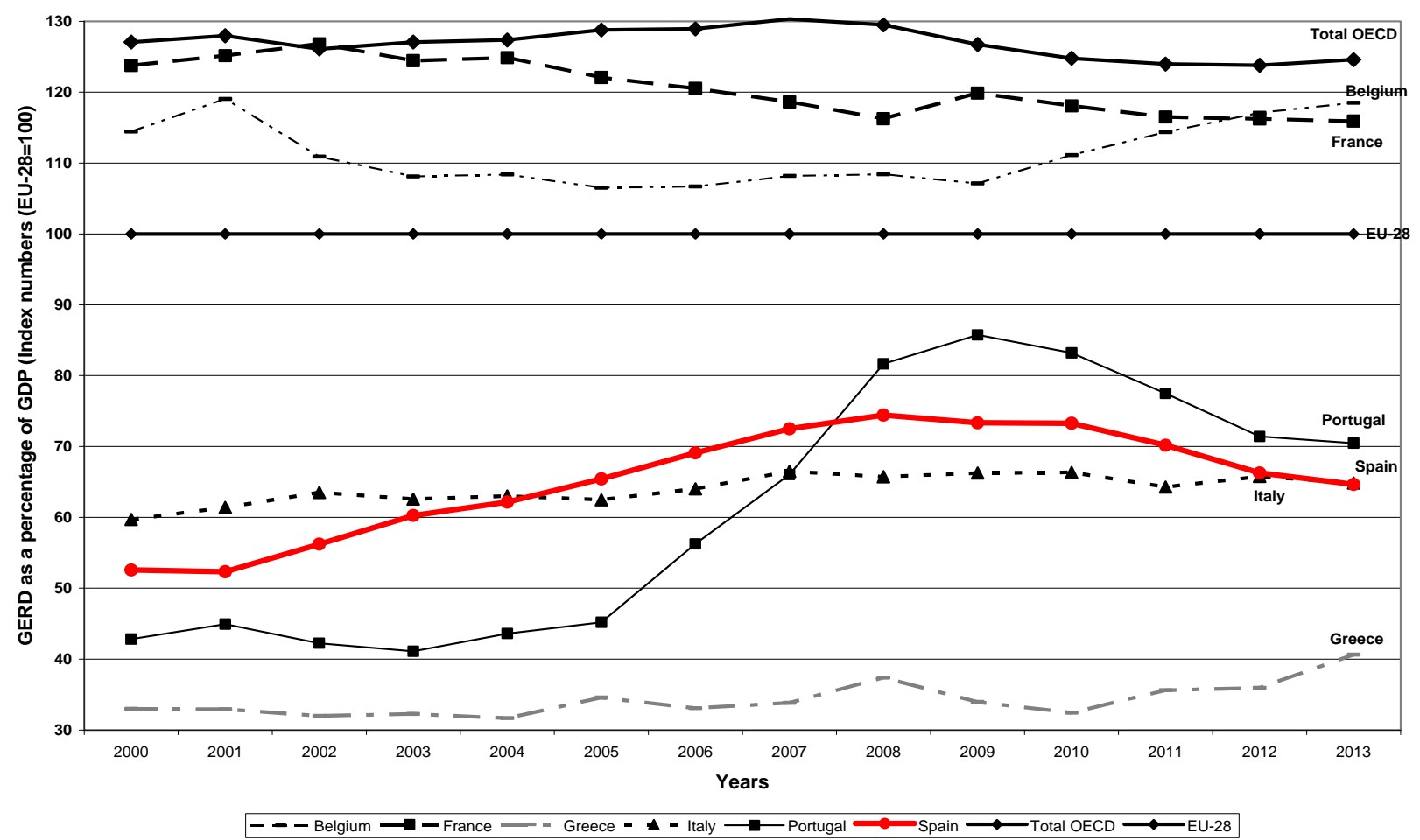

Source: OECD (2014) Main Science and Technology Indicators, June 2014

Thus, it appears that one of the initial effects of the crisis has been to halt the creation of R\&D capabilities and to move backwards in terms of convergence in R\&D intensity.

\section{c) Government budgets for $R \& D$}

The government budget appropriations and outlays for R\&D (GBAORD) data represent the quantity of resources that governments allocate annually to R\&D, regardless of whether the resources are spent directly on government facilities or on funding the activities of other actors, either public or private; it is also an indicator of the priority that governments give to the R\&D public budgets in comparison with other areas of public expenditure, as well as a reflection of the structure of expenditure between sectors, socioeconomic objectives and policies.

Average GBAORD values in the OECD and the EU28, in comparison with GDP, have been quite stable over recent decades (0.7\%); however, there are structural differences between countries and trends. The quantity of resources allocated to R\&D depends on policy priorities, government preferences, national expenditure structures and also the fiscal resources available to invest in R\&D confronted with other priorities and obligations.

Very few countries in the OECD have increased their share of GBAORD in GDP in the period from 2009 to 2012. In many countries 2009 was the year of the establishment of fiscal stimulus packages and, in some of them the R\&D budget rose, but later on only a few countries (Japan and Korea) some small European ones (Denmark, Austria, Estonia, Luxembourg) continued to increase 
GBAORD as a share of GDP. In general, after the crisis, as Figure 3 shows, most of the selected countries have significantly reduced their public budgets for R\&D. The share of GBAORD over the total government budget provides some information regarding the effect of the debt crisis on R\&D public funding. The Spanish case is one of severe reduction ${ }^{6}$.

Figure 3. Share of the Public Budget for R\&D (GBAORD) over GDP. 2000-2012.

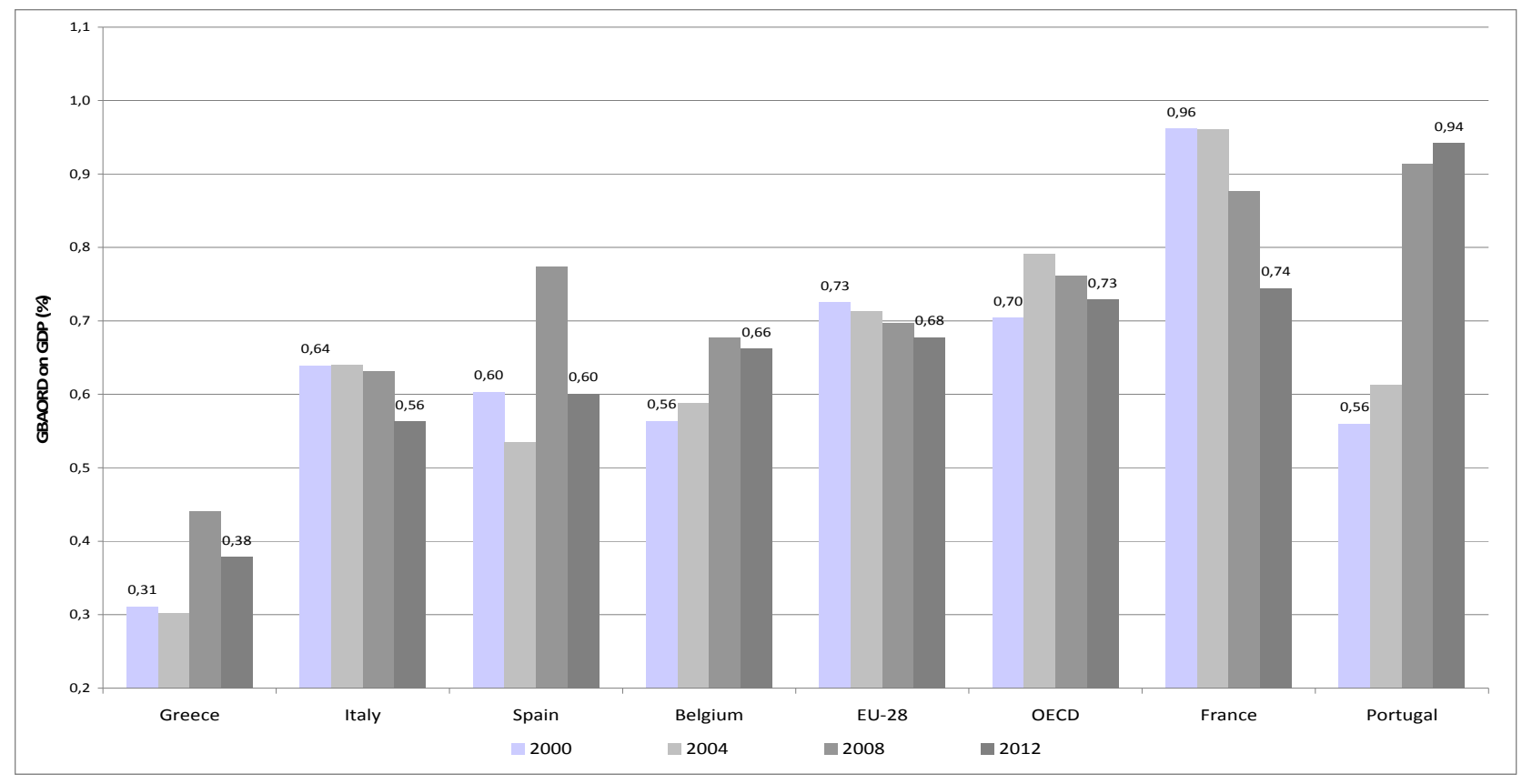

Source: OECD (2014) Main Science and Technology Indicators, June 2014

A further way of addressing the comparison between countries with different sizes is to look at the relationship between government budget per capita and GBAORD per capita. For the complete set of European countries the correlation is very high, but a clear view of the priorities and constraints can be obtained when we follow the value over time, as represented in Figure 4, depicting the situation in 2004, 2009 and 2012. For Portugal and Greece we see a simultaneous reduction of government budget per capita and GBAORD per capita between 2009 and 2012, while for Italy and Spain a stagnation of government budgets per capita and a reduction of GBAORD per capita can be observed.

\footnotetext{
${ }^{6}$ The rise in interest rates for the Southern European countries has increased the deficit (in many cases as the result of the increase in debt repayments) and therefore the share of the overall government budget in GDP. It is interesting to note the Portuguese situation, which maintains a higher political priority for public R\&D budgets, despite the effects of the crisis on GDP.
} 
Figure 4. General government budgets per capita and government budgets for R\&D (GBAORD) per capita. 2004, 2009 and 2012

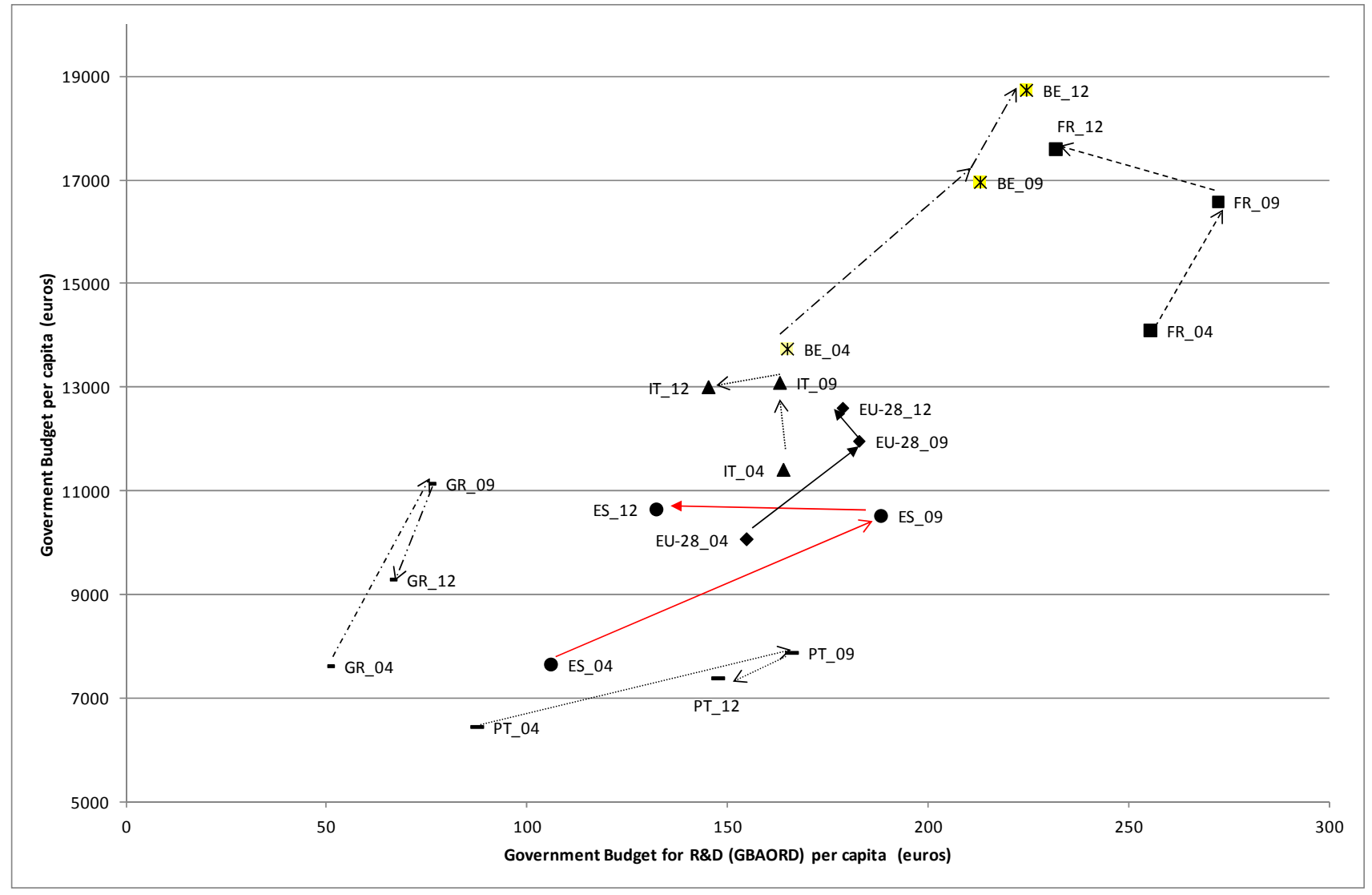

Source: OECD (2014) Main Science and Technology Indicators, June 2014 and

Eurostat. http://ec.europa.eu/eurostat/eurostat/tgm/table.do?tab=table\&init=1\&plugin=1\&language=en\&pcode=tec00023

\subsection{The Spanish case in depth}

Spain, considering fiscal and expenditure affairs, is a quasi-federal country (Cantarero \& González 2009). This affects research and innovation activities because the competences of steering, funding and supervising R\&D are shared between the national and the regional governments (Comunidades Autonomas). The national government has a national R\&D and innovation policy, with specific funding instruments, and also supervises a set of PROs. The regional governments have their own regional R\&D policies and they manage and supervise the higher education system and the public health provision system, including R\&D activities in hospitals in their territories; additionally, agricultural R\&D facilities were transferred to the regions some time ago; these three areas account for a significant share of public sector research (Sanz-Menéndez and Cruz-Castro 2005).

The regional governments make a significant contribution to the funding of the R\&D system because they oversee the universities in their regions and they transfer direct appropriations for higher education to the public universities under their control. There is not much systematic data which could be used to account for the contribution of each government level to the funding of the overall R\&D system. Data for 2006, produced by the Spanish Statistical Office (INE) showed that the 
contribution of the national and regional governments to the funding of the public sector was $44 \%$ and $56 \%$ respectively ${ }^{7}$; regional governments mainly contributed to funding their own public universities through direct appropriations for the higher education system $170 \%$ of their total resources to R\&D performers), while the central government mainly funded big national PROs (50\% of its allocation) and provided most of the competitive funding in the national system, both for academic researchers (25\%) and for business (25\%).

\section{a) The R\&D public budget: the funders' perspective}

The national and regional budgetary statistics provide a general picture of the evolution of the funds approved and spent every year. From 2005 both national and regional governments witnessed a significant expansion of their aggregate public expenditure that also affected their R\&D budgets $^{8}$. As Figure 5 shows (in index numbers), the striking expansion of the total budgets for R\&D in the national and regional governments halted suddenly in 2009.

Figure 5. National and Regional Government-Budgets for R\&D. Index numbers (2005 = 100).

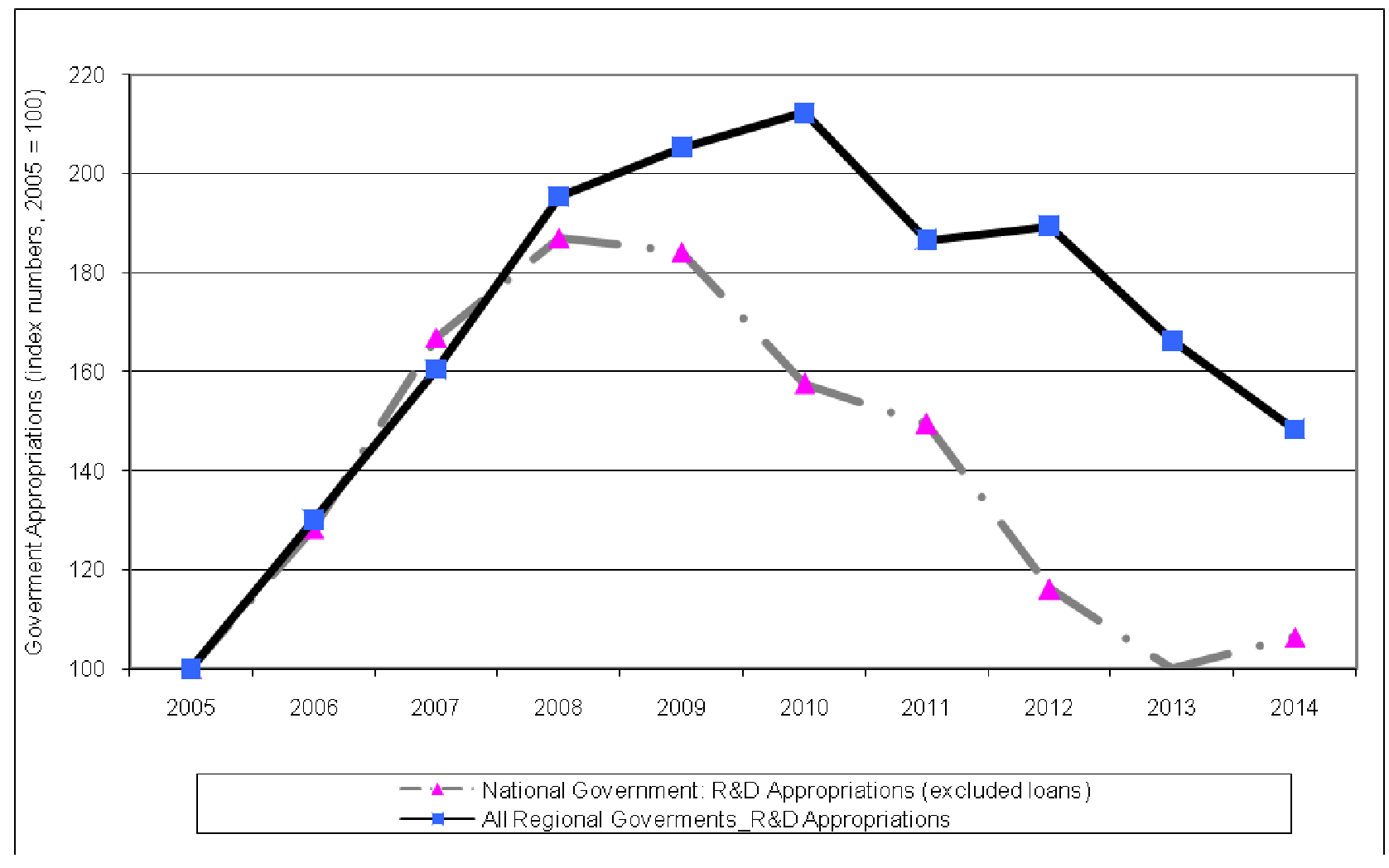

Source: FECYT using Ministry of Treasury budget data

In order to properly compare the respective contribution of the national and regional governments to R\&D funding we have included subsidies, grants and direct transfers and excluded repayable loans. The R\&D budget almost doubled between 2005 and 2008, yet after 2009 the reduction was

\footnotetext{
${ }^{7}$ INE. Estadística de Actividades de I+D, www.ine.es

${ }^{8}$ We should note again that higher education budgets are not included in the R\&D budgets.
} 
faster in the national government than in its regional counterparts ${ }^{9}$. The fact is that in 2013 the national R\&D public budget at nominal values was similar to that of 2005 , meaning a reduction in real terms of more than $11 \%$.

Since 2008 the reductions in the levels of R\&D budgets of the national government for grants and direct appropriations (with a historical maximum of 4,238 Meuros) have been greater than in the regions. The approved 2013 R\&D budget was 2,266, meaning 46.5\% less than 5 years earlier and representing an accumulated reduction (in comparison with a hypothetical scenario of a frozen budget at the 2008 level) of 5,154 Meuros, a figure more than double the grants and subsidies expected for 2013.

The first decade of this century also witnessed a significant increase in the resources approved in the regional government budgets. In 2002 the total regional R\&D budgets available was 682 Meuros $(0.75 \%$ of the total regional budgets approved), rising to a total amount of 2,741 Meuros in 2010 (1.49\% of the total regional budgets). The source of additional available funding was the improvement of the fiscal arrangements between the regions and the central government, together with funding approved by European Structural Funds. However, in most recent years, the regional governments' priority for R\&D in their general budgets diminished in the context of general budget cuts and, in 2013, the share of the R\&D budget in the total R\&D regional budget was $1.3 \%$ of the total. The amount fell to 2,148 Meuros, a figure similar to the level of 2007 . The accumulated reduction between 2010 and 2013, in terms of funding supplied by the regions to the R\&D system represented over 1,200 Meuros. The 17 regional governments have reduced their budgets for R\&D by $15 \%$ on average in the last 3 years, reaching in 2013 a level $21.7 \%$ lower than the amount in 2010.

\section{b) The R\&D public performers}

In the previous section we have analyzed the budgets for R\&D approved by the national and regional governments. They represent the amount allocated for the purpose of developing direct or supporting indirect R\&D performance. In this section, we analyse the issue from the point of view of the R\&D public performers and their budgets.

\section{Government Research Centres}

An issue worthy of mention is that in the years prior to the crisis the public budgets for S\&T grew extraordinarily, including: new permanent positions for civil servants, new temporary funding programs for the training and employability of researchers, new investments and construction of facilities, etc. This growth, between 2005 and 2008, raised expectations among the actors in the R\&D system.

\footnotetext{
${ }^{9}$ The expectation derived from the process of recentralization and increasing control of the regional governments budgets by the national government would be a much bigger reduction in the budget allocated by the regions. However the Act of Budget Stability and Financial Sustainability (LO 2/2012, April 27), was approved in 2012, and therefore the effects of the reinforced controls over regional budgets could take some time to become visible in the statistics.
} 
Figure 6. National Government Budgets for R\&D: Direct performance of PROs and Ministry funding activities. Index numbers (2005 = 100).

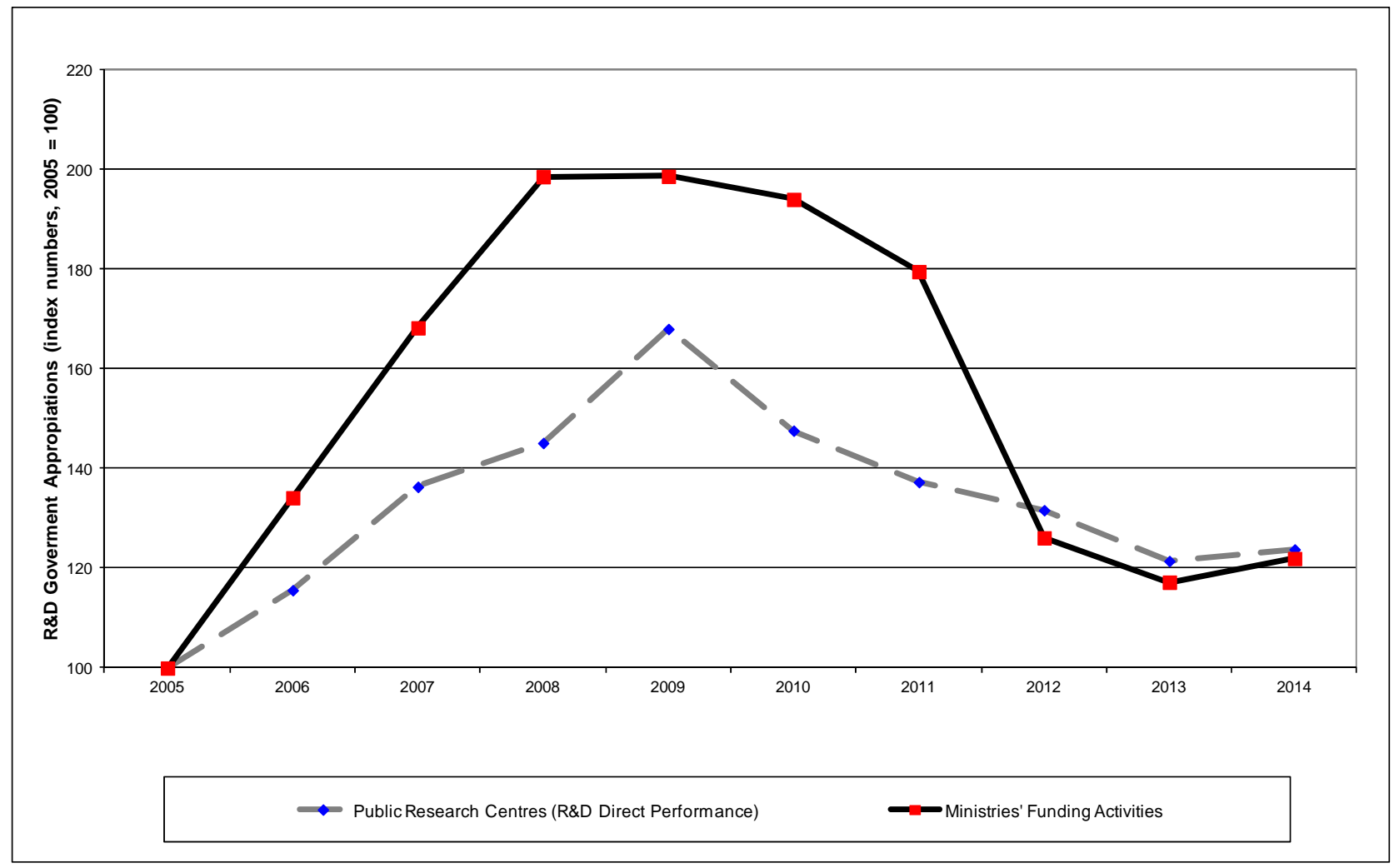

Source: FECYT using Ministry of Treasury budget data

As Figure 6 reveals, the national budget share for funding R\&D grew faster before the crisis than ever before. In the first two years of the crisis the reduction in the funding for direct performance of research in PRO was very rapid and then, due to the special nature of the allocations for PRO (mostly fixed personnel costs of civil servants), the process could not go beyond $2013 .{ }^{10}$ It seems that in times of recession governments cut first what it is easier to cut: discretionary nonearmarked appropriations and competitive funding.

A recent report analysing the impact of the budget cuts in government research centres estimates an average of 27.6\% aggregate budget reduction between 2009 and 2013 (CC.OO, 2013), with some centres suffering cuts of up to $40 \%$. Considering only the CSIC (the National Research Council), the budgets implemented in 2009 were 850 Meuros, while in 2014 the amount was only 650 Meuros (CSIC Annual Reports).

\section{Public universities}

The budgets for funding the regular activities of public higher education institutions are not included in the R\&D government budgets, as they have a separate budget line. This is why it is

\footnotetext{
${ }^{10}$ To illustrate the emergency situation that the budgetary practices created between 2009 and 2011, we may mention as an example the situation of quasi-bankruptcy of the National Research Council (CSIC) in July 2013 which was extensively covered in the media (see footnote 3 ).
} 
important to monitor the higher education budget, to obtain a better perspective of the impact of the crisis and budget cuts on the public research system. Public universities in Spain (except for two distance learning universities) depend on regional governments' financial support and direct transfers. In the context of a radical reduction of the regional governments' budgets to cope with the debt crisis, the budgets of public universities have also diminished very significantly since 2009.

Despite the increase in students' fees that have raised the income of universities, budget reduction been very significant. The comparison between the aggregate figure of the university budgets approved in 2010 (the highest year) was 10,118 Meuros, versus 8,730 Meuros in 2013 (1,388 Meuros less); this represents a $13.7 \%$ reduction (plus $8.7 \%$ price deflator) which is $22.4 \%$ less in real terms. Because the priority given to universities is very different among regional governments, there are also important differences in the budget reduction between regions and universities. Figure 7 represents the variation in university budgets cuts.

Figure 7. Changes in public university budgets by source of political dependence: $2010-2013$ (in \%)

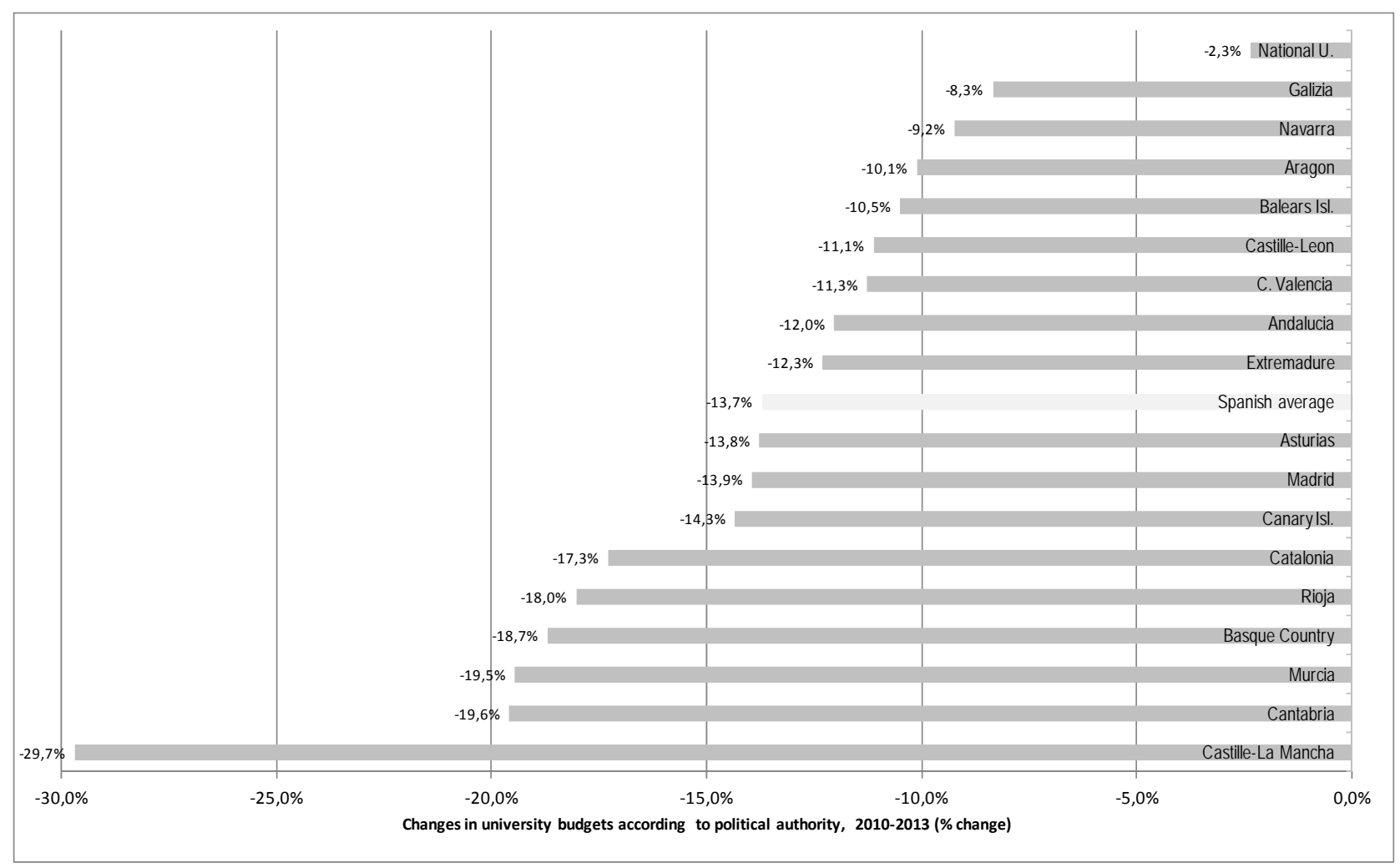

Source: CC.OO (2014). Using university budget data

\section{c) Regulations and control measures in R\&D policy and management}

The overview of the quantitative indicators shown in the figures provides a general picture of the impact of fiscal consolidation policies on the level of R\&D resources. In this section we introduce some additional elements to assist understanding of the effects of the crisis on some of the foundations of the R\&D system: incentive systems, authority structures, and levels of actors' trust in public support. 
In addition to the budget cuts and the reduction of resources (including those targeted at R\&D employment) the Spanish public administration has undertaken other actions, more closely related to regulations and procedures that have been implemented in the public R\&D sector. There has been an increase in the operational controls of the Treasury over the ministry in charge of R\&D policy, of the ministry and regional governments towards the research centres and public universities, and within the research centres down to the individual institutes and research units. This has occurred along with a process of the recentralization of managerial and administrative competences in the top managers of all institutions with increasing dependence on the supervisory levels.

\section{Budgetary and management practices}

It should be noted that Spanish general budgetary procedures have been characterised as having low levels of flexibility (OECD 2014). As regards the supervision of expenditure of the Ministry of Economy and Competitiveness (in charge of R\&D) by the Ministry of the Treasury three budget management practices are worth mentioning.

Firstly, a commonly used budgetary practice that relates to the mix of policy tools mix is the balance between 'grants' and 'repayable loans' in the R\&D budget. The national budget for R\&D has two main forms of appropriations: 'subsidies, grants and transfers' and 'repayable loans' (the so-called chapter VIII of the budget: financial assets), and three main methods of operation: a) direct appropriations for PROs (including some nominal assignments), that could be considered block grants, but most of them are earmarked, b) competitive funding allocations to different types of actors (PROs, universities, regions, individuals and firms), by means of projects or fellowships, including grants and loans and c) tax advantages for companies. The last of these are included in the budget as "fiscal expenditure", while the two previous items form part of expenditure budgets.

Since the last decade governments have publicly stated their commitment to R\&D, but most of the increases in appropriations have been through "repayable loans", which usually represent over half of the total national government budget for R\&D. Increases in the repayable loans chapter could balance the total (if subsidies were reduced) and give the public the impression that the budget is balanced or growing. Every year a significant amount of these loans are not used (COSCE 2014, IGAE 2014). It is our contention that repayable loans are rather ineffective as R\&D policy tools in times of crisis; they create the fiction that the overall budget is not decreasing but neither public sector research centres nor firms can easily provide the financial guarantees required by the loans. Additionally, in a context of low interest rates neither do companies make use of them, meaning their overall policy value is very limited. Consequently, examining only the approved total R\&D budget could be misleading, as every year a significant part of loans is not used.

Secondly, regarding the management of the approved budget, the Spanish Ministry of the Treasury has used the so-called "budget non-availability orders", a procedure by which the Treasury 
operates daily control of spending commitments and payment flows ${ }^{11}$. Regardless of what the approved annual national budget appropriations establish, the use of this mechanism implies a de facto political decision to freeze expenditure when necessary. This type of practice allows for the maintenance of 'expansionary' budgets on paper, while at the same time keeping real spending subjected to administrative-political decisions, which take into account flows of incoming revenue or changes in the interest rates of the debt supporting these budgets. The most direct consequences of this practice are increased delays in payments for approved commitments and a delay in public calls for competitive funding until the Treasury's expectation regarding the overall deficit become clearer; this generates uncertainty, hampers the planning of research organisations and creates significant problems for the units managing the competitive funding resources in the Ministry. ${ }^{12}$

Thirdly, a new budget control practice came into force in 2012; because R\&D budgets are approved annually, including only the quantity of resources already committed and with almost no new discretionary funds, to implement policy and to allow for new commitments of resources (and new public calls), "extraordinary appropriations" were approved. They consist in the passing of budgetary increases in the middle of the budgetary year. ${ }^{13}$ Although their approval may provide a signal that the government is taking care of priorities, in fact they are a means for providing the resources which were not included in the annual budget approved previously; extraordinary appropriations create problems of implementation, due to the need to commit the resources before the end of the budgetary year. The outcome is often that Ministries and research centres need to spend quickly under considerable management stress, and controllers (under the direct orders of the Treasury in each Ministry) tend not to authorize the issue of public calls until the funds are effectively in the ministries' accounts, which is always several weeks later, following approval by Government and ratification by Parliament.

These last two practices illustrate how policies and their corresponding budget appropriations may remain null and void and make clear that the use of aggregate macro statistical figures (especially of the budgets initially approved) is not sufficient for the study of R\&D budgets, especially competitive funding streams. In this context tool-based policies become ineffective and inefficient. Eventually, at the end of the year a significant proportion of the funds initially approved appear as

\footnotetext{
${ }^{11}$ Legal capacity was established in the 2003 General Budgetary Act in favour of the Ministry of the Treasury and subsequently reinforced by some further normative changes. In 2012, the Organic Law of Budgetary Stabilization and Financial Sustainability expanded the control and enforcement mechanism to the budgets of the regional governments to guarantee overall national fiscal discipline.

12 On many occasions Spanish newspapers, and especially El País, have published front pages complaining about the delays and changes in the planning of the public calls or about the delay in the payments determined by the Treasury availability when it establishes a clear order of priorities for expenditure that places R\&D at a disadvantage. (See for example: "Alarma entre los científicos por el retraso en el Plan Nacional de I+D", EL PAIS, 20 December 2011. http://sociedad.elpais.com/sociedad/2011/12/20/actualidad/1324414608 470757.html or "Los científicos se quedan este año sin proyectos del Plan Estatal”, 2013. http://sociedad.elpais.com/sociedad/2013/04/18/actualidad/1366318556 147323.html

${ }^{13}$ For example, extraordinary appropriations for $R \& D$, to provide resources for regular functioning, were approved on 28 June 2013 (RDL 7/2013) for 104 Meuros, on 18 October 2013 (RDL 12/2013) for 70 Meuros, on 20 June 2014 (RDL 7/2014) for 95 Meuros and on 14 May 2015 (RDL 6/2015) for 95.6 Meuros.
} 
"non-used". We can cite, for example, the reports at the end of the year 2014 issued by the IGAE (general accounting office) and collected by COSCE (2015), which give the aggregate figure of unused R\&D budgets at around $40 \%$ of the authorizations approved by Parliament.

In sum, policy measures taken as a reaction to the economic crisis have reduced the capacity of governments to control the public R\&D system. Due to their non selective nature, budget cuts, together with regulations emphasizing administrative controls, have strongly reduced government capacity to define spending priorities and coordinate the system; moreover, because of their effects on competitive funding, these practices have increased the levels of uncertainty within the system and reduced trust among actors.

\section{Human resources for $R \& D$}

The structure of employment in PROs and public universities is dual: a set of permanent staff (researchers, technicians and support staff), most of whom are civil servants, and a set of temporary fixed-term staff contracted under the general regular labour regulations (Cruz-Castro and Sanz-Menéndez 2015). Temporary contracted staff are funded by research projects financed by the different public administrations and by specific public calls for human resources (for PhD students and trainees, postdoctoral grants ( 3 and 5 years), technicians, etc.).

The second area in which recentralization is present in the system refers to the management of human resources for $R \& D$ in the public research sector. In this regard, we can distinguish between, on the one hand, measures affecting situations vacant and working conditions and, on the other, regulations regarding general labour relations and management.

Among the first is noteworthy the decision in 2010 to freeze the calls for new public permanent positions and to leave the replacement rate for retirements at the $10 \%$ level in all public sector organizations (including universities, PROs, etc) ${ }^{14}$. Additionally, as a result of the public budget cuts, the national and regional governments have reduced the project grants, fellowships and contracts financed directly through competitive calls, leading to a shrinking number of temporary and project-based contracted researchers. ${ }^{15}$ Together with such job reductions, working conditions were affected in two ways: on the one hand, salaries of all personnel in the public sector were cut, affecting both civil servants as well as contracted staff (a 15\% reduction for two years in a row 2010 and 2011- and frozen since then); on the other hand, an increase in the teaching loads of university professors and lecturers was approved ${ }^{16}$.

\footnotetext{
${ }^{14}$ This government decision was maintained up to the year 2015 , in which the government raised the replacement rate to $50 \%$ of annual retirements. The consequences, in terms of the total number of permanent staff are obvious: a reduction in the number of employees in universities and PROs.

15 For example the number of annual fellowships funded directly by the national government fell from 7,000, representing 360 Meuros in 2009 to 2900, or a figure of 160 Meuros in 2012 (FECYT: Memorias de Actividades de I+D+I, various years).

${ }^{16}$ RDL 14 /2012, 20 April, concerning "urgent measures of rationalization of public expenditure in the educational sector".
} 
Additionally, in the area of labour relations and human resource management, an automatic procedure for the cancelation of permanent positions of people who moved to other organizations or jobs was established, removing the control of turnover from the local managers of public sector organisations. This movement represented a complete centralization of human resource policies in the hands of the Ministry of the Treasury and PROs and universities were no longer permitted to create or replace positions in their organisations up to the legal ceiling.

On the general legislative side, two reforms of the labour market (2010 and 2012) modified the conditions by which temporary researchers used to become permanent ${ }^{17}$. Finally, public organisations (including universities and PROs) were allowed to approve collective "layoffs" in the context of the crisis, provided they could claim a situation of budget deficit ${ }^{18}$.

\section{Regular management and administrative processes}

These interventions in the budgetary practices and the human resources areas have coexisted with a significant centralisation process of decision making to the upper levels of the administrative structures, in both the higher education and public research sectors.

Since the crisis, the approval of every competitive call from the Ministry in charge of R\&D policy (regardless of the availability of money) should have the visa of the Ministry of Treasury, a practice associated to the main government objective: reducing public expending.

In addition, a reduction of the political autonomy of the PROs and the public universities vis $a$ vis the Ministry or the regional governments has taken place; the traditional delegation of authority to the performing units has diminished. In the context of raising efficiency in the public administration an increased centralisation of the approval of procurement, contract and collaboration agreements and hiring has occurred. ${ }^{19}$

The combined analysis of the data, showing declining resources together with the practical dynamics of budget implementation, human resources management and regulatory practices, reveals that macro statistical data for planned budgets alone fall short of accounting for the real operational constraints on research introduced as a consequence of the crisis. The adjustment indicated by the macro figures has been amplified by powerful expenditure contention mechanisms which are strategically implemented by the government.

Paradoxically, in the same years in which the first generation of 'control' initiatives were taken, two Acts with different approaches to crisis management were passed: the Law for Sustainable

\footnotetext{
${ }^{17}$ This affected all researchers and personnel under the Contractual "Private" Labour Law, by excluding fixed term and temporary contracts in the public research sector from the limit of 3 years after which a temporary worker became "permanent" (with an open-ended contract).

${ }^{18}$ Some universities, such as the Polytechnic University of Madrid, have already used this new tool, with 300 people dismissed in March 2013. See for example: "La Politécnica despide a 301 empleados". EL PAIS 9 March 2013.

http://ccaa.elpais.com/ccaa/2013/03/09/madrid/1362860483 707543.html

${ }^{19}$ For example, in institutions like the CSIC the ability to make decisions based on institutional agreements has been removed from the institutes' directors' hands.
} 
Economics (30 March 2010 to 4 March 2011 (BOE) and the Law of Science (15 May 2010 and 1 June 2011 (BOE). The two new Acts included some suggested changes with a focus on flexibility for the $R \& D$ and innovation system that were obviously more rhetorical than practical and seemed rather contradictory, given the rigidities introduced by the transversal measures just reviewed.

In short, most of the relevant changes in the functioning of the public universities and the research institutions have not evolved from changes contained in these sector-specific Acts but mainly as a result of the general reforms transversally affecting all sectors (e.g. public administration reform measures, labour market reform, etc).

\section{Concluding remarks: the institutional weaknesses of public research organizations in dealing with the crisis}

The financial and regulatory measures taken by governments in the context of the crisis have greatly affected public research organizations. The crisis has had obvious consequences in terms of shrinking budgets, reduction of competitive funding, increasing the constraints and rigidities in the management of human resources and the recentralization of competencies. In this final section, we would like to link those measures taken by governments and some key institutional features of Spanish public research organizations.

Legislation and a more interventionist and regulatory governmental approach entail a loss of administrative autonomy for universities and PROs with regard to their funders (regional governments and national ministries, respectively). As mentioned above, this has been implemented through a reduction of delegation to the performing units, resulting in more centralised organizations. Due to their lack of flexibility in the management of their own financial and human resources, Spanish public research organizations are poorly equipped to cope with and react to the policy environment derived from the crisis, for example, by diversifying funding sources.

In line with Bozeman (1986) we should acknowledge that not all public organisations share the same features; put another way, they do not have the same degree of "publicness", defined as the combination of different forms of ownership, funding and control (Cruz-Castro, Martinez and SanzMenéndez 2012). The two main types of organizations of the Spanish public research sector are, on the one hand, government-owned research centres (PROs), managed under the general public administration regulations, and, on the other hand, public universities, favoured with constitutional management autonomy under specific public regulations.

Actors in the R\&D system respond and adapt to existing and changing incentives. Universities and PROs function under the public sector regulations and enjoy collectively negotiated salary and working conditions, a circumstance which precludes them from selectively affecting the salaries and working conditions of individual researchers and constraining their capacity to attract and retain in the job market. The reduction of salaries, the freezing of the number of new positions and the limitation of Spanish public competitive funding which supports project-based research contracts 
and positions illustrate a pattern of stagnation, especially in comparison with the previous period of expansion, as described above. Permanent researchers complain about the reduction of salaries and about the increasing competition and pressure for limited resources; young researchers face difficult prospects in terms of career consolidation and tenure; in the context of increasing competition for fewer and fewer positions they start to think of leaving the sector or moving to a different country to pursue their research career; for example, the CSIC-National Research Council reduced the number of employees by 4,000 between 2013 and 2014, a figure representing 25\% (CC.OO. 2014).

In complex organisations, managers are in charge of allocating common resources (and establishing incentives). The reduction of direct financial transfers described in this paper, the limitations on how many positions can be allocated, or the problems of keeping the joint facilities of the research institutes functioning are likely to significantly reduce managerial or administrative authority vis a vis researchers. The directors of these public organizations distribute and allocate fewer and fewer resources and researchers have to search for external competitive resources individually, and so once they secure resources for their own projects they become decoupled from or more independent of the authority structure.

The need of permanent researchers to obtain their own external funds, combined with the reduction of the role of management derived from a situation of shrinking resources are prone to create collective action problems in public sector organizations. PROs and public universities have been analytically characterised as organizations with limited actorhood (Krucken and Meier 2006, Whitley 2010), and the crisis is likely to limit the ability of such organisations to mobilise individuals in search of common strategies even more.

Moreover, in public research organizations populated by civil servants (as they are in the Spanish case) management cannot control the dynamics of exit; in other words, its capacity to organise selection and retention is very limited. In this context, there is the risk that those with better chances (and maybe of a higher quality) leave the organisation while others stay, to exert the "voice" option or simply "neglect" the situation.

Finally, one basic principle of R\&D systems is the need for stability. The crisis and its effects increase uncertainty in all domains and budget cuts and reductions of opportunities send messages that affect the level of trust among actors; in this context the confidence of researchers in the political and policy system is eroded, while at the same time researchers' complaints send messages to the international community and overall confidence in the national system becomes reduced. ${ }^{20}$ In the worst case scenario, this is a self-reinforcing dynamic in which all actors adjust their behaviour and whereby the degree of international integration of the Spanish R\&D system could become negatively affected.

To sum up, according to their current features Spanish public research centres and universities are constrained in their capacity to respond to the crisis, partly because they cannot really choose;

\footnotetext{
${ }^{20}$ See footnotes 1 to 4.
} 
their autonomy is very limited, and the result is a natural selection process based on a "muddling through" dynamic (Lindbloom 1959).

In order to be in a better position to adjust and to be ready for the way out of the crisis, public research organisations should be equipped with more managerial autonomy, be able to make choices (even if they are hard choices) and establish priorities related to functionality or performance. General budget cuts together with increased regulation might increase administrative costs and reduce incentives without any efficiency gains. Policymakers in the field of science and technology should warn their colleagues in the Treasury that general measures with a single objective (budget expenditure contention) implemented with no margin of self adjustment at the lower levels could preclude the selectivity needed to keep the R\&D system as competitive as possible. Budget officials should bear in mind that there are tradeoffs between applying general non-selective cuts and the capacity of government to establish priorities in particular policy domains like research. ${ }^{21}$

We acknowledge that the analysis presented in this paper is rooted in the specificities of the Spanish case; we believe, however, that it is an interesting international case in which fiscal consolidation and adjustment measures have been quite significant.

*. Funding is acknowledged from the Ministry of Economy and Competitiveness (grant CSO2011-29431).

\section{References}

Afonso, A. and Tovar Jalles, J. (2013) "The cyclicality of education, health, and social security government spending”. Applied Economics Letters ,20 (7), 669-672.

Archibugi, D. and Filippetti, A. (2011). "Is the Economic Crisis Impairing Convergence in Innovation Performance across Europe?, Journal of Common Market Studies, 49 (6), 1153-1182.

Archibugi, D., Filippetti, A, and Frenz, M. (2013). "The impact of the economic crisis on innovation: Evidence from Europe”, Technological Forecasting \& Social Change, 80 (7), 1247-1260.

Barlevy, G. (2007). “On the Cyclicality of Research and Development”, The American Economic Review, 97 (4), 11311164.

Blekesaune, M.; Quadagno, J. (2003) 'Public Attitudes toward Welfare State Policies: A Comparative Analysis of 24 Nations”, European Sociological Review, 19 (5): 415-427.

Blekesaune M. and Quadagno, J., Public Attitudes toward Welfare State Policies: A Comparative Analysis of 24 Nations, European Sociological Review 19 (5), 2003, 415-427.

Boden, R., Cox, D., Nedeva, M., \& Barker, K. (2004). Scrutinising Science: The Changing UK Government of Science. Houndmills - New York: Palgrave- Macmillan.

Boden R., Cox D., Nedeva M., and Barker K., Scrutinising Science: The Changing UK Government of Science, 2004, Palgrave-Macmillan; Houndmills-New York.

Bozeman, B. (1986). All organizations are public: Bridging public and private organization theories. San Francisco: Jossey-Bass, 1986

Cantarero, D. and Pérez González, P. (2009). "Fiscal Decentralization and Economic Growth: Evidence from Spanish Regions”. Public Budgeting \& Finance 29 (4), 24-44

\footnotetext{
${ }^{21}$ A case of a sensible budget official decision confronting budget cuts in R\&D should be mentioned. The Regional Government of Catalonia, by the Regional Law 7/2011, 27 July of Fiscal and Financial Measures, established the nonapplicability of the general rules of the budgetary and human resource management in the institutions of the Catalan research sector.
} 
CC.OO. (2013), Los Organismos Públicos de Investigación (OPIs) en los PGE 2013, marzo 2013, Confederación Sindical de Comisiones Obreras. Secretaria de Investigación, Desarrollo e Innovación, Madrid . (last Access on June 28 2014).

CC.OO (2014). Evolución de los Presupuestos de las Universidades Públicas 2009-2013. Madrid: Comisiones Obreras de la Enseñanza. Last Access: 28 june 2014. http://www.fe.ccoo.es/comunes/recursos/25/1793265Estudio_Evolucion_de_los_presupuestos_de_las_universidades_publicas_\%282009-2013\%29.pdf. (Last access on March 14th 2015).

Cincera, M., Cozza, C, Tübke, A. and Voigt, P (2011). Doing R\&D or not (in a crisis), that is the question.... IPTS WORKING PAPER on CORPORATE R\&D AND INNOVATION - No. 12/2010 - updated ISSN 1831-9408

Cincera M., Cozza C., Tübke A. and Voigt P., Doing R\&D or Not (in a Crisis), That Is the Question ..., European Planning Studies 20 (2), 2012, 1525-1547.

Comin, D. and Gertler, M. (2006), “Medium-Term Business Cycles”, The American Economic Review, 96 (3), $523-551$.

Correa, P. and Iootty, M. (2011). R\&D Decisions during the Crisis: Firm-Level Evidence for Selected Eastern Countries. World Bank Group. Enterprise Note $n^{\circ} 21,2011$.

COSCE (2014). Análisis de los recursos destinados a I+D+I (Política de Gasto 46) contenidos en los Presupuestos Generales del Estado aprobados para el año 2014. http://www.cosce.net/pdf/informe_COSCE_inversion_ImasD_PGE2014_25feb14.pdf (last access on March 14th 2015)

COSCE (2015). Análisis de los recursos destinados a I+D+I (Política de Gasto 46) contenidos en los Presupuestos Generales del Estado aprobados para el año 2015. http://www.cosce.net/pdf/informe_COSCE_PGE_febrero_2015.pdf (last access on March 14 2015).

Cruz-Castro, L., Holl, A., Rama, R. and Sanz-Menéndez, L. (2015). "Economic crisis and corporate innovation in Spain: regional factors that matter". IPP working paper.

Cruz-Castro, L., Sanz-Menéndez, L. and Martínez, C. (2012), "Research centers in transition: patterns of convergence and diversity", The Journal of Technology Transfer 37 (1): 18-42.

Cruz-Castro, L, and Sanz-Menéndez, L. (2015). 'Policy Change and Differentiated Integration: Implementing Spanish Higher Education Reforms”, Journal of Contemporary European Research 11 (1): 103-123.

De Miguel, S. Moya-Anegon, F. and Herrero-Solana, V. (2010). "The impact of the socio-economic crisis of 2001 on the scientific system of Argentina from the scientometric perspective”, Scientometrics 85: 495-507.

Moya-Anegón F., Chinchilla-Rodríguez Z., Corera-Álvarez E., López-Illescas C. and Vargas-Quesada B., (2014) Indicadores Bibliométricos de la Actividad Científica Española 2011, 2014, Fundación Española para la Ciencia y la Tecnología, FECYT; Madrid.

European Commission (2014) “European Economic Forecast”. European Economy 2|2014.

European Commission (2015). The Innovation Union Scoreboard 2015. Brussels: European Union.

Filippetti, A. and Archibugi,D. (2011). "Innovation in times of crisis: National systems of innovation, structure, and demand”, Research Policy 40 (2): 179-192.

Hall, P.A. and Soskice, D. (eds.) (2001). Varieties of Capitalism. The Institutional Foundations of Comparative Advantage. Oxford: Oxford University Press.

Hirschman, A.O. (1970). Exit, voice and loyalty. Princeton: Princeton University Press

Holl, A. and Rama, R. (2015). “Economic crisis and innovation: Do regions matter?” Submitted to Regional Studies

I.G.A.E., Presupuestos generales del Estado. Avance de la Liquidación del Presupuesto de 2014. Volumen I (Estado). Ministerio de Hacienda y Administraciones Públicas; Madrid. http://www.igae.pap.minhap.gob.es/sitios/igae/esES/EjecucionPresupuestaria/Documents/AVANCE\%20ESTADO_2014\%20\%28INTERNET\%29.pdf (last access June 20 2015).

Izsak, K., Markianidou, P., Lukach, R., and Wastyn, A. (2013). The impact of the crisis on research and innovation policies. Study for the European Commission DG Research by Technopolis Group Belgium and Idea Consult.

Jacoby, W. G. (1994) 'Public Attitudes toward Government Spending’, American Journal of Political Science, 38 (2): $336-$ 361.

Jacoby W.G., Public Attitudes toward Government Spending, American Journal of Political Science, 38 (2), $1994,336-361$.

Kastrinos, N. (2013). “The financial crisis and Greek R\&D policy from a Schumpeterian perspective”, Science and Public Policy 40 (6), 779-791

Kim, S. Y. (2014). “Government R\&D funding in economic downturns: Testing the varieties of capitalism conjecture”. Science and Public Policy 41: 107-118.

Krucken, G. and F. Meier (2006) "Turning the University into an Organizational Actor," pp. 241-257 in G S Drori, J W Meyer and H Hwang (eds.) Globalization and Organization: World Society and organizational change, Oxford: Oxford University Press, 241-257.

Lindblom, C.E. (1959). ”The Science of "Muddling Through"”, Public Administration Review, 19 (2), 79-88

Makkonen, T. (2013). “Government science and technology budgets in times of crisis”, Research Policy, 42 (3): $817-$ 822. 
OECD (2009). Policy Responses to the Economic Crisis: Investing in Innovation for Long-Term Growth. Paris: OECD, June 2009.

OECD (2011). Public Research Institutions. Mapping sector trends. Paris: OECD.

OECD (2013). Government at a glance 2013. Paris: OECD.

OECD (2014). Budgeting Practices and Procedures in OECD Countries. Paris: OECD.

Paunov, C. (2012). “The global crisis and firms' investments in innovation”, Research Policy, 41 (1), 24-35.

Rusbult, C. E., Zembrodt, M., and Gunn, L. K. (1982). "Exit, voice, loyalty, and neglect: Responses to dissatisfaction in romantic involvements”. Journal of Personality and Social Psychology, 43, 1230-1242.

Sanz-Menéndez, L. and Cruz-Castro, L. (2005). "Explaining the science and technology policies of regional governments", Regional Studies, 39 (7): 939-954.

Sanz-Menéndez, L. and Van Ryzin, G.G. (2015). "Economic crisis and public attitudes toward science: A study of regional differences in Spain”, Public Understanding of Science, 24 (2): 147-166.

Tanzi, V. and Schuknecht, L. (1997). "Reconsidering the Fiscal Role of Government: The International Perspective”. The American Economic Review, 87 (2), 164-168.

Whitley, R. (2010). 'Reconfiguring the Public Sciences: the Impact of Governance Changes on Authority and Innovation in Public Science Systems’, in Whitley, R.; J. Glaser, and L. Engwall (eds.), Reconfiguring Knowledge Production: Changing Authority Relationships in the Sciences and their Consequences for Intellectual Innovation. Oxford: Oxford University Press, pp. 3-47. 